\title{
KEBIJAKAN KRIMINAL DALAM PENANGGULANGAN TINDAK PIDANA PENGANIAYAAN MENGGUNAKAN PANAH WAYER OLEH ANAK DI KOTA GORONTALO
}

\author{
(Studi Kasus Polres Gorontalo Kota)
}

\author{
Moh. Rusdiyanto U. Puluhulawa, Jufryanto Puluhulawa, \\ Moh. Fahrurrozie Hidayatullah Nur Musa \\ Program Studi Ilmu Hukum, Fakultas Hukum, Universitas Negeri Gorontalo \\ Jl. Jend. Sudirman No. 6, Kelurahan Dulalowo Timur, Kecamatan Kota Tengah, Kota \\ Gorontalo, Provinsi Gorontalo. Kode Pos 96128 \\ Email :mohamadrusdiyanto@yahoo.co.id,jufryantopuluhulawa@ung.ac.id
}

\begin{abstract}
Abstrak
Penelitian ini didasari situasi keamanan dan ketertiban umum yang kurang kondusif pada malam hari di Kota Gorontalo dimana pelakunya adalah anak-anak sehingga penelitian ini bertujuan untuk mengetahui faktor penyebabnya dan mengkaji kebijakan kriminal dalam penanggulangan permasalahan ini. Metode pendekatan Yuridis - Empiris. Hasil penelitian, 1) faktor penyebab tindak pidana penganiayaan menggunakan panah wayer oleh anak adalah lingkungan pergaulan tidak sehat, mengendurnya ikatan sosial dan keluarga, penyalahgunaan NAPZA serta adanya dorongan-dorangan ide dan sikap yang dibentuk oleh media massa. 2) kebijakan kriminal penanggulangan kejahatan dapat diimplementasikan dengan cara : mempengaruhi pandangan masyarakat mengenai kejahatan dan pemidanaan melalui media massa, penerapan hukum pidana dan pencegahan tanpa pidana. Sehingga ada korelasi antara jalur penal dan non penal. Saran, optimalisasi tupoksi media massa guna pembangunan budaya hukum nasional serta mengurangi konten yang berisi kekerasan atau asusila, harmonisasi keluarga inti, pemutusan rantai peredaran NAPZA serta junjung tinggi supremasi hukum dengan tetap memperhatikan kepentingan terbaik bagi anak.
\end{abstract}

Kata Kunci: Kebijakan Kriminal, Panah Wayer, Anak

\begin{abstract}
This study is based on a situation of security and public order that is less conducive at night in Gorontalo City where the perpetrators are children so this study aims to determine the causes and examine criminal policies in overcoming this problem. Juridical approach method - Empirical. The results of the study, 1) the factors causing criminal acts of persecution using wayer arrows by children are an unhealthy social environment, slackening of social and family ties, drug abuse and the encouragement of ideas and attitudes formed by the mass media. 2) Criminal crime prevention policies can be implemented with influencing public views on crime and crimes through the mass media, application of criminal law and prevention without crime. So there is a correlation between the path of reasoning and non-reasoning. Suggestions, optimization of the mass
\end{abstract}


media's main function to develop a national legal culture and reduce content that contains violence or immorality, harmonization of the nuclear family, breaking the chain of drug trafficking and upholding the rule of law while still taking into account the best interests of children.

Keywords: Criminal Policy, Wayer arrows, Children

\section{A. PENDAHULUAN}

\section{Latar Belakang}

Indonesia mendeklarasikan diri sebagai negara yang berlandaskan hukum dalam kehidupan berbangsa dan bernegaranya. Hal ini sebagaimana tertuang dalam Pasal 1 Ayat (3) UUD 1945 amandemen ketiga. Penegasan ketentuan konstitusi ini bermakna, bahwa "segala aspek kehidupan dalam kemasyarakatan, kenegaraan dan pemerintahan harus senantiasa berdasarkan atas hukum, tidak berdasarkan kekuasaan belaka (machtsstaat)."

Indonesia sebagai negara hukum tentunya memiliki tujuan yang secara jelas dituangkan dalam Undang-Undang Dasar Republik Indonesia Tahun 1945 yang menyatakan bahwa "negara bertujuan untuk melindungi segenap bangsa Indonesia dan seluruh tumpah darah Indonesia, memajukan kesejahteraan umum, mencerdaskan kehidupan bangsa, ikut serta dalam upaya perdamian dunia berdasarkan kemerdekaan, perdamaian abadi dan keadilan sosial."

Tujuan negara Republik Indonesia tersebut, termaksud didalamnya adanya perlindungan bagi masyarakat dan ada hak-hak masyarakat yang dijamin dalam setiap aspek kehidupannya. Hal ini tentunya sejalan dengan konsep negara hukum yang

${ }^{1}$ Diana Halim Koentjoro. Hukum Administrasi Negara. Ghalia Indonesia. Bogor. 2004. hlm. 34- 
dicetuskan oleh F.J. Stahl yang salah satunya adalah "memberikan pengakuan dan perlindungan terhadap hak asasi manusia."2

Pada kenyataannya didalam realitas kehidupan masyarakat, berbanding terbalik dengan tujuan negara Indonesia. Berbagai macam permasalahan hukum telah terjadi. Pola tingkah laku manusia pun semakin menyimpang dan keluar dari norma-norma yang tumbuh dalam masyarakat dan mengakibatkan terjadinya pelanggaran bahkan kejahatan yang berujung pada terlanggarnya hak asasi manusia.

Salah satu bentuk kejahatan yang berkembang dalam masyarakat dan merupakan suatu tindak pidana adalah penganiayaan. Penganiayaan dalam Kamus Besar Bahasa Indonesia merupakan "perbuatan sewenang-wenang (penyiksaan, penindasan, dan sebagainya) untuk menyakiti orang lain dengan sengaja dan menimbulkan kerugian baik berupa rasa sakit, luka atau kerugian kesehatan orang lain." ${ }^{\prime 3}$ Penganiayaan sendiri telah diatur dalam Pasal 351 ayat (1) Kitab Undang-undang Hukum Pidana (KUHP).

Perkembangan dewasa ini, tindak pidana penganiayaan yang ada mulai menggunakan alat bantu berupa panah wayer yang bentuknya berupa anak panah bergerigi dengan bahan dasar besi atau alumunium yang ditembakkan dengan perantara ketapel atau pelontar karet. Tindak pidana penganiayaan menggunakan panah wayer ini sering ditujukan kepada kaum lemah seperti wanita dan anak. Namun berjalanya waktu, faktanya, anak bukan lagi menjadi korban melainkan mulai bertransformasi sebagai pelaku tindak pidana.

2 Padmo Wahjono Dalam Marwan Effendy. Teori Hukum Dari Perspektif Kebijakan, Perbandingan dan Harmonisasi Hukum Pidana. Referensi. Ciputat. 2014. hlm. 49

3 Badan Pengembangan dan Pembinaan Bahasa Kementerian Pendidikan dan Kebudayaan Republik Indonesia. Kamus Besar Bahasa Indonesia Versi Daring: 1.4.9.2-20190308150813. https://kbbi.kemdikbud.go.id/entri/penganiayaan Diakses 18-03-2019 
Fenomena anak menjadi pelaku tindak pidana penganiayaan menggunakan panah wayer khususnya di Kota Gorontalo dapat dilihat dari maraknya berita di media cetak, yakni

"seorang pengemudi ojek online bernama Muhammad Tasdik (29) menderita luka di bagian dada kanan akibat tertusuk panah wayer di Jalan Bali, Kecamatan Kota Tengah, Kota Gorontalo. Mirisnya, para pelaku masih ABG. Bahkan dua di antaranya adalah pelajar SMA. RY (19), RA (17), dan AM (17) ditangkap di lokasi berbeda, Selasa (12/2)."

Dalam kasus yang berbeda, sebagaimana diberitakan oleh Beritatagar.id ${ }^{5}$

"Rabu (13/2) lalu, tim Alap-Alap Satreskrim Polres Gorontalo Kota mengamankan 11 orang siswa SMP-SMA yang diduga terlibat dalam kasus penembakan panah wayer di Jalan Tri Brata, Kelurahan Ipilo, Kecamatan Kota Timur, Kota Gorontalo, pada hari yang sama. Korbannya adalah teman sebaya mereka, Galang Saido (15).”

Hal ini tentunya sangat memprihatinkan, dimana anak dibawah umur memainkan peran utama dalam teror panah wayer di serambi madinah ini. Data terbaru yang penulis peroleh dari Polres Gorontalo Kota juga semakin menegaskan eksistensi anak dalam tindak pidana penganiaayan menggunakan panah wayer yakni sebagai berikut;

Tabel 1. Data Tindak Pidana Penganiayaan yang Dilakukan Oleh Anak Menggunakan Panah Wayer Di Polres Gorontalo Kota

\begin{tabular}{|c|c|c|}
\hline No. & Tahun & Jumlah \\
\hline 1 & 2017 & 4 Kasus \\
\hline 2 & 2018 & 12 Kasus \\
\hline 3 & 2019 & 5 Kasus \\
\hline \multicolumn{2}{|c|}{ Total } & 21 Kasus \\
\hline
\end{tabular}

Sumber dari : Polres Gorontalo Kota, April 2019

\footnotetext{
${ }^{4}$ Franco Dengo. Teror Panah Wayer Menghantui Kota Gorontalo. Beritatagar.id. 14 Feberuari 2019. https://beritagar.id/artikel/berita/teror-panah-wayer-menghantui-kota-gorontalo . Diakses 20 Maret 2019

${ }^{5}$ Franco Dengo. Teror Panah Wayer Di Gorontalo Belum Berhenti. Beritatagar.id 1 Maret 2019. https://beritagar.id/artikel/berita/teror-panah-wayer-di-gorontalo-belum-berhenti. Diakses 20 Maret 2019
} 
Jumlah kasus tindak penganiayaan menggunakan panah wayer ini tentunya sangat meresahkan. Saking meresahkannya Kapolres Gorontalo Kota yakni AKBP. Robin Lumban Raja melalui Kasat Reskrim Polres Gorontalo Kota, AKP Handy Senonughroho dalam keterangan persnya menyatakan "Jika ada masyarakat ataupun anggota yang terancam nyawanya, saya perintahkan untuk tidak segan-segan tembak pelaku di tempat. Tindakan mereka bisa menghilangkan nyawa siapapun dan mereka sangat liar menyasar siapa saja." Pernyataan tegas ini jelas merupakan bentuk respon terhadap maraknya teror panah wayer yang menimbulkan ketakutan tersendiri bagi masyarakat dalam beraktifitas khususnya di malam hari.

Tindakan tegas jelas diperlukan akan tetapi yang perlu diperhatikan adalah pelaku teror merupakan anak-anak. Perlu langkah khusus dalam penanggulangan hukumnya. Hal ini mengingat anak merupakan generasi penerus bangsa sekaligus bibit muda pembawa harapan pembaharuan bangsa terlebih lagi eksistensi dari anak mendapatkan etensi khusus dari negara dalam berbagai peraturan perundang-undangan.

Dalam kosideran Undang-Undang Nomor 23 Tahun 2002 tentang Perlindungan Anak, dikatakan bahwa :

"Anak adalah amanah dan karunia Tuhan Yang Maha Esa, yang dalam dirinya melekat harkat dan martabat sebagai manusia seutuhnya. Lebih lanjut dikatakan bahwa anak adalah tunas, potensi, dan generasi muda penerus cita-cita perjuangan bangsa, memiliki peran strategis dan mempunyai ciri dan sifat khusus yang menjamin kelangsungan eksistensi bangsa dan negara pada masa depan. Oleh karena itu agar setiap anak kelak mampu memikul tanggung jawab tersebut, maka ia perlu mendapat kesempatan yang seluasluasnya untuk tumbuh dan berkembangsecara optimal, baik fisik, mental maupun sosial, dan berakhlak mulia, perlu dilakukan upaya perlindungan serta mewujudkan kesejahteraan anak dengan memberikan jaminan terhadap pemenuhan hak-haknya serta adanya perlakuan tanpa diskriminasi."

\footnotetext{
${ }^{6}$ Franco Dengo. Loc. Cit
} 
Hal ini diatur juga dalam Pasal 28B ayat (2) Undang-Undang Dasar Negara Republik Indonesia Tahun 1945. Tergambar jelas dari amanah peraturan perundangundangan yakni tumbuh kembang anak merupakan esensi yang perlu mendapatkan atensi masyarakat luas terlebih khusus pemangku kebijakan dan pelaksananya di lapangan akan tetapi disisi lainnya kenakalan anak merupakan suatu ancaman terhadap norma-norma sosial yang mendasari kehidupan atau keteraturan sosial yang dapat menimbulkan konflik. "Kenakalan anak di samping merupakan masalah kemanusiaan juga merupakan masalah sosial, sehingga penanganan kenakalan anak merupakan tanggungjawab bersama anggota masyarakat", ${ }^{7}$ teristimewa dalam hal ini adalah penegak hukum.

\section{Rumusan Masalah}

a. Faktor apa yang menyebabkan terjadinya tindak pidana penganiayaan menggunakan panah wayer oleh anak di Kota Gorontalo?

b. Kebijakan kriminal apa yang dapat dilakukan oleh kepolisian terhadap anak yang melakukan tindak pidana penganiayaan menggunakan panah wayer di Kota Gorontalo ?

\section{Metode Penelitian}

Metode pendekatan yang digunakan dalam mengkaji permasalahan dalam penelitian ini adalah

“metode pendekatan Yuridis - Empiris yaitu penelitian yang menitikberatkan pada perilaku individu atau masyarakat dalam kaitannya dengan hukum, penelitian hukum empiris memberikan arti penting terhadap analisis yang bersifat kuantitatif dan empiris, sehingga langkah dan desain teknis penelitian

${ }^{7}$ Maidin Gultom. Perlindungan hukum terhadap anak dalam Sistem Peradilan Pidana anak di Indonesia, PT. Rafika Aditama. Bandung. 2008. hlm. 61 
tersebut mengikuti pola dari penelitian ilmu sosial khususnya ilmu sosiologis (socio-legal research)." 8

Dalam hal ini penulis melakukan penelitian di Polres Gorontalo Kota terkait tindak pidana penganiayaan menggunakan panah wayer oleh anak.

\section{B. HASIL DAN PEMBAHASAN PEMBAHASAN}

\section{Faktor Yang Menyebabkan Terjadinya Tindak Pidana Penganiayaan Menggunakan Panah Wayer Oleh Anak Di Kota Gorontalo}

Tindak pidana yang dilakukan oleh anak dalam hal ini penganiayaan menggunakan panah wayer merupakan masalah yang serius dalam kehidupan bermasyarakat di Kota Gorontalo dalam kurun waktu 3 tahun terakhir ini, terlebih lagi terjadi peningkatan dari tahun ke tahun, sehingga diperlukan perhatian khusus, teristimewa terhadap faktor - faktor yang menjadi akar permasalahan yang menyebabkan semakin maraknya tindak pidana ini. Senada dengan hal tersebut, dalam Kongres PBB Mengenai The Prevention of Crime and The Treatment of Offenders, menaruh perhatian terhadap dimensi perkembangan kejahatan antara lain dalam "Kongres ke 5 Tahun 1975 di Geneva, pada poin 4 meminta perhatian terhadap perbuatan kekerasan antar-perorangan (interpersonal violance), khususnya di kalangan remaja.",9

Menurut Kongres PBB ke 8, faktor yang berkontribusi sebagai penyebab kejahatan khususnya dalam masalah urban crime yakni:

1. "Kemiskinan, pengangguran, kebodohan; hlm.93

${ }^{8}$ Peter Mahmud Marzuki. Penelitian Hukum. Kencana Prenada Media Group. Jakarta. 2010.

${ }^{9}$ Barda Nawawi Arief. Barda Nawawi Arief. Bunga Rampai Kebijakan Hukum Pidana. Fajar Interpratama. Semarang. 2011. Hlm. 15 
2. Meningkatnya jumlah penduduk yang tidak mempunyai prospek (harapan) karena proses integrasi sosial, juga karena memburuknya ketimpangan sosial;

3. Mengendurnya ikatan sosial dan keluarga;

4. Keadaan / kondisi yang menyulitkan bagi orang-orang yang berimigrasi ke kota-kota atau negara-negara lain;

5. Rusaknya atau hancurnya identitas budaya asli, yang bersamaan dengan adanya rasisme dan diskriminasi menyebabkan kerugian / kelemahan di bidang sosial, kesejahteraan dan dalam lingkungan pekerjaan;

6. Menurunnya kualitas lingkungan perkotaan yang mendorong peningkatan kejahatan dan berkurangnya (tidak cukupnya) pelayanan bagi tempattempat fasilitas lingkungan/bertetangga;

7. Kesulitan - kesulitan bagi orang-orang dalam masyarakat modern untuk berintegrasi sebagaimana mestinya di dalam lingkungan masyarakatnya, di lingkungan keluarga, tempat kerjanya atau di lingkungan sekolahnya;

8. Penyalahgunaan alkohol, obat bius, dan lain-lain yang pemakaiannya juga diperluas karena faktor-faktor yang disebutkan diatas;

9. Meluasnya aktivitas kejahatan yang terorganisasi, khususnya perdagangan obat bius dan penadahan barang curian;

10.Dorongan-dorangan ide dan sikap (khususnya mass media) yang mengarah pada tindakan kekerasan, ketidaksamaan (hak) atau sikap-sikap intoleransi." $" 10$

Kaitannya dengan fenomena yang terjadi di Kota Gorontalo terkait maraknya penganiayaan menggunakan panah wayer oleh anak, AKP. Deni Nuhtamar, S.Sos.,SH. ${ }^{11}$ menuturkan "faktor lingkungan dalam hal ini lingkungan pergaulan dari anak menjadi penyebab utama terjadinya kriminalitas." 12 Sebagaimana teori asosiasi diferensial yang dikemukakan oleh Edwin H. Sutherland dimana "pola

10 Eight UN Congress. Dokumen A/CONF.144/L.3 Dalam Yesmil Anwar dan Adang. Pembaharuan Hukum Pidana ; Reformasi Hukum Pidana. Grasindo. Jakarta. 2008. hlm. 14

11 Kasat Reskrim Polres Gorontalo Kota, menggantikan AKP Handy Senonughroho

${ }^{12}$ Wawancara di Unit IV (PPA) Satuan Reskrim Polres Gorontalo Kota Tanggal 7 Agustus 2019 
perilaku jahat itu tidak diwariskan dari orang tua tetapi dipelajari melalui suatu pergaulan yang akrab."13 Pola ini juga ditegaskan oleh pelaku yang merupakan anak-anak yakni RY alias Iki (19), ${ }^{14}$ “dimana mereka melakukan penembakan menggunakan panah wayer ini awalnya hanya karena ide atau ajakan dari temannya, jadi bukan murni keinginan dari yang bersangkutan.” Pertemanan yang tidak sehat tentunya akan menjerumuskan anak kepada perbuatan memyimpang maupun perbuatan melawan hukum karena melihat karakteristik anak-anak yang pada umumnya masih labil, masih mencari identitas diri dan mengharapkan pengakuan terhadap eksistensi dirinya.

Penulis berpendapat, dalam lingkup Kota Gorontalo sebagaimana hasil pengamatan penulis yang disertai juga dengan diskusi dengan beberapa narasumber , bahwasannya jika dikaitkan dengan sudut pandang Kongres PBB ke 8, faktor lingkungan pergaulan ini juga erat kaitannya dengan mengendurnya ikatan sosial dan keluarga, penyalahgunaan alkohol, obat-obat terlarang dan zat adiktif, serta adanya dorongan-dorangan ide dan sikap yang dibentuk oleh media massa.

Permasalahan mengendurnya ikatan sosial dan keluarga sebagai dampak dari modernisasi dan industrialisasi. "Sikap sekuler era modern, anti tradisional dibeberapa daerah tertentu, penempatan kerja berdasarkan keahlian, sistem kelas terbuka dan mobilitas geografis yang tinggi"15, harus diakui memberikan dampak signifikan terhadap ikatan sosial padahal dalam sebuah ikatan sosial diperlukan “interaksi sosial yang meliputi kontak sosial dan adanya komunikasi."16 Disisi lain

\footnotetext{
${ }^{13}$ Lilik Mulyadi. Kajian Kritis dan Analitis Terhadap Dimensi Teori-Teori Kriminologi Dalam Perspektif Ilmu Pengetahuan Hukum Pidana Modern. Pengadilan Negeri Kepanjen. Malang. 2009. hlm. 4

${ }_{14}$ Fajriansyach. Tiga Pelaku Panah Wayer Dibekuk, Ini Orangnya. http://hargo.co.id/berita/tigapelaku-panah-wayer-dibekuk-ini-orangnya.html . 13 Februari 2019. Diakses 21-08-2019

${ }^{15}$ William J. Goode. Sosiologi Keluarga. Bumi Aksara. Jakarta. 1991. hlm. 210

${ }^{16}$ Soerjono Soekanto. Sosiologi Suatu Pengantar. Raja Grafindo Persada. Jakarta. 1994. hlm. 71
} 
bagi keluarga, dalam pandangan Wilodati ${ }^{17}$, "kurangnya komunikasi antar keluarga dapat melemahkan ikatan nuclear family, juga kurang teratur dan intensifnya kontak antar keluarga dapat mengakibatkan melemahnya ikatan extended family."

Disorganisasi keluarga ini tidak dapat dipungkiri berdampak pada pembentukan intelektual dan mental anak yang mengakibatkan terjadinya penyimpangan perilaku sosial anak ketika memasuki masa remaja. Hal ini ditegaskan oleh Sartini Nuryoto yang menyatakan bahwa ${ }^{18}$ "dari berbagai kasus negatif yang terjadi diluar rumah terutama yang dilakukan oleh anak diduga kuat berakar dari kondisi interaksi antara orang tua dan anak yang kurang harmonis." Oleh karena itu diperlukan harmonisasi dalam keluarga agar efektifnya penanggulangan tindak pidana oleh anak ini.

Penyalahgunaan alkohol dan obat-obat terlarang serta zat adiktif tak dapat dipungkiri juga menjadi akar permasalahan dari terjadinya tindak pidana di kalangan anak-anak maupun remaja. Contoh nyata adalah "kejadian penembakan panah wayer oleh dua orang pelaku yang masih anak-anak di Jalan Palma, Kelurahan Libuo, Kecamatan Dungingi, Kota Gorontalo pada bulan April 2019 ini, dimana para pelaku dalam pengaruh zat adiktif yakni lem perekat serbaguna.”19

Data Badan Narkotika Nasional (BNN) Republik Indonesia berdasarkan hasil survei di 13 provinsi menegaskan, “diproyeksikan kalangan pelajar dan mahasiswa yang pernah merasakan minuman beralkohol, sebanyak $26,7 \%$ pernah

\footnotetext{
17 Wilodati. Pengoptimalisasian Kembali Fungsi Keluarga Sebagai Peletak Dasar Kepribadian Anak. Jurnal Keluarga. Universitas Pendidikan Indonesia. hlm. 4

${ }^{18}$ Sartini Nuryoto. Tebar Kemesraan Orang Tua-Anak. Pikiran Rakyat. Bandung. 1993. Dalam Wilodati. Ibid. hlm. 5

${ }^{19}$ Arimin J. Wumu. Polsek Dungingi Kota Gorontalo Amankan Dua Pelaku Penembakan Panah Wayer Yang Meresahkan Warga. http://antpnews110.com/polsek-dungingi-kota-gorontalo-amankan-duapelaku-penembakan-panah-wayer-yang-meresahkan-warga/ . 7 April 2019. Diakses 21-08-2019.
} 
merasakan mabok akibat meminum minuman beralkohol." ${ }^{20} \mathrm{Hal}$ ini diperkuat oleh Kepala Bidang P2M BNN Provinsi Gorontalo menegaskan "saat ini dikalangan generasi muda marak konsumsi rokok, penggunaan minuman keras serta ngelem atau penggunaan zat adiktif." 21 Fenomena ini jelas mengkhawatirkan karena tentunya ketika dalam kondisi tidak sadarkan diri akibat pengaruh dari minuman beralkohol dapat menimbulkan kerentanan terhadap perilaku beresiko sebagai akibat dari hilangnya kontrol diri serta menurunnya kemampuan berpikir logis, dimana perilaku beresiko tersebut termasuk didalamnya adalah tindak pidana yang tentunya akan berdampak pada meningkatnya angka kriminalitas yang berujung pada keresahan di kalangan masyarakat.

Dalam sajian data lainnya terkait penggunaan obat-obat terlarang atau disebut juga dengan narkotika atau napza "berdasarkan angka prevelensi pemakaian narkoba dikalangan pelajar dan mahasiswa, secara keseluruhan terdapat 3,2\% atau setara 2,297,492 orang yang sudah terpapar narkoba yang lebih jelasnya dapat dilihat dari tabel berikut :"22

\section{Tabel $2 .^{23}$}

Angka Prevelensi Pernah Memakai Narkoba dan Memakai Narkoba 1 Tahun Terakhir di Kalangan Pelajar dan Mahasiswa Menurut Tingkat Pendidikannya (\%)

\begin{tabular}{|c|c|c|c|c|}
\hline \multirow{2}{*}{ Kategori } & \multicolumn{2}{|c|}{ Pernah Pakai } & \multicolumn{2}{c|}{ Pakai 1 Tahun } \\
\cline { 2 - 5 } & $\mathrm{N}$ & $\%$ & $\mathrm{~N}$ & $\%$ \\
\hline SMP & 63 & $4,8 \%$ & 43 & $3,3 \%$ \\
\hline SMA & 127 & $6,4 \%$ & 71 & $3,6 \%$ \\
\hline PT & 113 & $6 \%$ & 53 & $2.8 \%$ \\
\hline Total & 303 & $5,8 \%$ & 167 & $3,2 \%$ \\
\hline
\end{tabular}

20 Badan Narkotika Nasional Republik Indonesia dan LIPI. Executive Summary Survey Penyalahgunaan dan Peredaran Gelap Narkoba 2018. hlm. 19. https://ppid.bnn.go.id/wpcontent/uploads/sites/2/2019/02/hasil_lit_bnn_2018.pdf. Diakses 20-08-2019

${ }^{21}$ Badan Narkotika Nasional Provinsi Gorontalo. Banyak Remaja Miras \& Ngelem, Ini Pesan Kabid P2M BNNP Gorontalo. https://gorontalo.bnn.go.id/beritakegiatan/banyak-remaja-miras-ngelem-inipesan-kabid-p2m-gorontalo/. Diakses 20-08-2019

${ }^{22}$ Ibid. hlm. 14

${ }^{23}$ Ibid. 
Sumber : Survei Penyalahgunaan dan Peredaran Gelap Narkoba, 2018

Untuk Kota Gorontalo berdasarkan daftar kawasan rawan narkoba di Indonesia Tahun 2019 yang diterbitkan oleh Badan narkotika Nasional Republik Indonesia, "dari 3 (tiga) wilayah yang masuk kategori rentan dan rawan narkoba di Provinsi Gorontalo, duanya berada di Kota Gorontalo yakni Kelurahan Biawu dan Kelurahan Biawao di Kecamatan Kota Selatan."24

Narkotika dan zat adiktif di kalangan anak dan remaja ini jelas harus mendapatkan perhatian serius dan melibatkan berbagai pihak termasuk Badan Narkotika nasional Provinsi gorontalo berkolaborasi dengan masyarakat Kota Gorontalo dalam hal ini yakni orang tua karena anak sebagai generasi muda adalah investasi bangsa yang harus dirawat dan diproteksi dari hal negatif. Pemutusan mata rantai narkotika serta penghilangan akses minuman beralkohol oleh anak tentunya menjadi syarat wajib bagi efektifnya penanggulangan tindak pidana.

Terlepas dari mengendurnya ikatan sosial dan keluarga serta penyalahgunaan alkohol dan obat-obat terlarang, peranan media massa juga memainkan posisi penting dalam tumbuh kembang anak saat ini. Informasi yang diterima akan membentuk kepribadian, pola pikir dan mentalitas anak.

Harus diakui, kita saat ini berada di era milenial, dimana semua akses begitu terbuka dan mudahnya untuk didapatkan. Hanya dengan kekuatan jempol melalui sarana smartphone atau gadget dengan dukungan akses internet maka semua informasi dapat kita dapatkan dengan begitu praktisnya. Youtube, Telegram, Instagram, Google, Kanal Berita Online dan masih banyak lagi merupakan

${ }^{24}$ Badan Narkotika Nasional Republik Indonesia. Daftar Kawasan Rawan Narkoba Di Indonesia Tahun 2019. hlm. 19. https://ppid.bnn.go.id/wp-content/uploads/sites/2/2019/07/Kawasan-RawanNarkoba.pdf. Diakses 20-08-2019 
segelintir platform yang mempermudah akses informasi dan komunikasi saat ini. Belum lagi eksistensi dari media elektronik nasional dalam bentuk siaran televisi yang meliputi siaran berita nasional maupun lokal, talkshow maupun sinema elektronik. Semua hal ini memberikan keterbukaan informasi dan komunikasi yang begitu luas, cepat dan tidak mengenal batas daerah ataupun negara, terlebih lagi juga tidak mengenal batasan usia.

Data yang di lansir Asosiasi Penyelenggara Jasa Internet Indonesia (APJJI) dari hasil survei melaporkan bahwa

“dari 256.2 juta orang di Indonesia, yang menggunakan internet ada setengahnya yaitu 132.7 juta jiwa, sedangkan untuk pengguna di kalangan remaja yakni 23,8 juta jiwa. Angka yang cukup fantastis ini membuat Indonesia berada dalam cengkraman media sosial." 25

Kondisi ini kemudian menempatkan media massa pada posisi strategis dalam kehidupan bermasyarakat sebagaimana dikemukakan oleh McQuail dalam bukunya Mass Communication Theories, ada enam perspektif dalam hal melihat peran media yakni:

1. "Melihat media massa sebagai window on event and experience. Media dipandang sebagai jendela yang memungkinkan khalayak melihat apa yang sedang terjadi di luar sana. Atau media merupakan sarana belajar untuk mengetahui berbagai peristiwa;

2. Media juga sering dianggap sebagai a mirror of event in society and the world, implying a faithful reflection.

Cermin berbagai peristiwa yang ada di masyarakat dan dunia, yang merefleksikan apa adanya. Karenanya para pengelola media sering merasa tidak "bersalah" jika isi media penuh dengan kekerasan, konflik, pornografi dan berbagai keburukan lain, karena memang menurut mereka faktanya demikian, media hanya sebagai refleksi fakta, terlepas dari suka

25 Anshar Tawaulu. Peranan Media Sosial dalam Membentuk Karakter Generasi Muda. https://www.kompasiana.com/pojokjalan/59b81bc6830de00acf4b98f2/peranan-media-sosial-dalammembentuk-karakter-generasi-muda . 13 September 2017. Diakses Tanggal 21-08-2019 
atau tidak suka. Padahal sesungguhnya, angle, arah dan framing dari isi yang dianggap sebagai cermin realitas tersebut diputuskan oleh para profesional media, dan khalayak tidak sepenuhnya bebas untuk mengetahui apa yang mereka inginkan;

3. Memandang media massa sebagai filter, atau gatekeeper yang menyeleksi berbagai hal untuk diberi perhatian atau tidak.

Media senantiasa memilih isu, informasi atau bentuk content yang lain berdasar standar para pengelolanya. Disini khalayak "dipilihkan" oleh media tentang apa-apa yang layak diketahui dan mendapat perhatian;

4. Media massa seringkali pula dipandang sebagai guide, penunjuk jalan atau interpreter, yang menerjemahkan dan menunjukkan arah atas berbagai ketidakpastian, atau alternatif yang beragam;

5. Melihat media massa sebagai forum untuk mempresentasikan berbagai informasi dan ide-ide kepada khalayak, sehingga memungkin terjadinya tanggapan dan umpan balik;

6. Media massa sebagai interlocutor, yang tidak hanya sekadar tempat berlalu lalangnya informasi, tetapi juga partner komunikasi yang memungkinkan terjadinya komunikasi interaktif."26

Pendapat McQuail ini menggambarkan media massa tidak hanya sebagai sarana tontonan pelepas penat, hiburan di waktu istirahat atau akhir pekan tetapi lebih luas lagi memberikan peran yang signifikan terhadap proses sosial masyarakat dan juga tumbuh kembang anak, bahkan dalam sudut pandang penulis, disadari atau tidak, media massa telah membawa bangsa ini dalam posisi transisi dari peradaban tradisional menuju peradaban modern, bahkan dalam kasus Indonesia saat ini melalui peranan media massa, nilai-nilai kehidupan serta budaya asli Indonesia mulai "terjajah" oleh kebudayaan barat yang tercermin dari gaya hidup masyarakat pada umumnya dan remaja pada khususnya yang hedonis, individualistis, 2000. hlm. 66

${ }^{26}$ McQuail, Denis. Mass Communication Theories, Fourth edition. Sage Publication. London. 
konsumtif dan bebas. Seirama dengan hal tersebut, Aria Aditya Setiawan menegaskan,

"isi dan informasi yang disajikan media massa, mempunyai peran yang signifikan dalam proses sosial. Isi media massa merupakan konsumsi otak bagi khalayaknya, sehingga apa yang ada di media massa akan mempengaruhi realitas subjektif pelaku interaksi sosial. Gambaran tentang realitas yang dibentuk oleh isi media massa inilah yang nantinya mendasari respon dan sikap khalayak terhadap berbagai objek sosial. Informasi yang salah dari media massa akan memunculkan gambaran yang salah pula terhadap objek sosial itu." ${ }^{27}$

Jelaslah bahwa peranan dan pengaruh dari media massa tidak dapat disepelekan eksistensinya sehingga pengendalian terhadap konten media massa, terlebih media sosial haruslah dilakukan dengan baik agar dapat menyajikan informasi yang akurat, lugas, terpercaya serta mendidik generasi bangsa.

\section{Kebijakan Kriminal Yang Dapat Dilakukan Polres Gorontalo Kota Dalam Penanggulangan Tindak Pidana Penganiayaan Menggunakan Panah Wayer Oleh Anak di Kota Gorontalo}

Penerapan hukum pidana dalam perjalanannya bagaikan pedang bermata dua. Frasa ini mengindikasikan bahwa hukum bisa memberikan kepastian hukum dan keadilan namun dapat juga memberikan kehancuran. "Hukum bisa efektif sebagai panduan dan pilar pengawasan sekaligus penegakan tata tertib bermasyarakat, disisi lainnya hukum dan penegakan hukum bisa digunakan sebagai senjata pembunuh sistem integritas nasional, dan membinasakan lawan politik tanpa pilih bulu." ${ }^{28}$

\footnotetext{
${ }^{27}$ Aria Aditya Setiawan. Peran Media Massa Dalam Meningkatkan Kualitas Kepemerintahan Lokal Berbasis Human Security di Kota Jayapura. Politika. Jurnal Ilmu Politik. 2(2). Hlm. 40

28 Hukum Online. Pedang Bermata Dua. Hukumonline.com ; 4 September 2014. https://www.hukumonline.com/berita/baca/lt540835393d0aa/pedang-bermata-dua/. Diakses 10 -8-2019.
} 
Kaitannya dengan anak yang berhadapan dengan hukum, Indira Hapsari, Eko Soponyono, R.B. Sularto dalam tulisannya menegaskan bahwa ${ }^{29}$

"Penerapan hukum pidana sebagai sarana penanggulangan kejahatan yang dilakukan olah anak pada dasarnya bersifat dilematis. Disatu sisi, penggunaan hukum pidana sebagai sarana penanggulangan kejahatan yang dilakukan anak dengan menempatkan anak sebagai pelaku kejahatan menimbulkan dampak negatif yang sangat kompleks, tetapi disisi lain penggunaan hukum pidana sebagai sarana penanggulangan kejahatan anak justru dianggap sebagai pilihan yang rasional dan legal."

Dilematis tentunya, karena kedua sisi pedang hukum pidana ini tidak bisa diterapkan secara bersamaan.

Jika mengacu pada teori retributif atau teori absolut yang diajukan oleh Immanuel Kant dan Hegel dimana "kejahatan dipandang sebagai perbuatan amoral sehingga harus dibalas dengan pemidanaan dimana tujuan pembalasan difokuskan pada pembalasan secara proporsional." ${ }^{30}$ Maka anak yang berhadapan dengan hukum juga harus dihukum karena harus mempertanggungjawabkan perbuatan amoral yang telah diperbuatnya dengan hukuman yang setimpal.

Disisi lain terdapat Teori Detterence yang dikenal juga sebagai teori relatif, salah satu tokohnya yakni Beccaria menegaskan dalam bukunya yang berjudul $d e i$ Delitti e Delle Pene (1764) bahwa "tujuan pemidanaan adalah untuk mencegah seseorang supaya tidak melakukan kejahatan, dan bukan sebagai sarana pembalasan masyarakat." 31 Teori ini menekankan pada pemidanaan untuk pencegahan agar

${ }^{29}$ Indira Hapsari, Eko Soponyono, R.B. Sularto. Kebijakan Hukum Pidana Dalam Upaya Penanggulangan Tindak Pidana Narkotika Pelaku Anak. Diponegoro Law Journal. Semarang. 2016. Hlm. 2

${ }^{30}$ Mahmud Mulyadi, Feri Antoni Surbakti. Politik Hukum Pidana Terhadap kejahatan Korporasi. PT Softmedia. Medan. 2010 hlm. 93.

${ }^{31}$ Ibid 
masyarakat menjadi takut serta lebih mengontrol diri untuk melakukan perbuatan amoral sehingga dapat mereduksi terjadinya kejahatan. Maka dalam sudut pandang ini, anak yang berhadapan dengan hukum juga mendapatkan pemidanaan guna memberikan efek jera pada diri anak sebagai pelaku dan juga memberikan efek warning pada masyarakat bahwa anak tidak diperlakukan spesial dalam kedudukannya sebagai anak-anak. Perspektif penulis, teori ini pun lebih manusiawi untuk dijadikan landasan teori dalam menggaungkan eksistensi pemidanaan anak yang disenergikan dalam sistem peradilan anak.

Perspektif berbeda dianut oleh Teori Treatment dimana "tujuan pemidanaan untuk memberikan tindakan perawatan dan perbaikan kepada pelaku kejahatan sebagai ganti dari pembalasan berupa penghukuman."32 Teori ini umumnya digunakan sebagai landasan filosofis dalam pemidanaan terhadap para pelaku penyalahgunaan narkotika dan psikotropika dimana para pelakunya membutuhkan perlakuan khusus serta rehabilitasi.

Realitas saat ini terdapat total 21 kasus tindak penganiayaan menggunakan panah wayer di Kota Gorontalo dan jumlah tersebut akan terus meningkat seiring berjalannya waktu, sebagaimana tergambarkan dalam tabel berikut :

Data Tindak Pidana Penganiayaan yang Dilakukan Oleh Anak Menggunakan Panah Wayer Di Polres Gorontalo Kota

\begin{tabular}{|c|c|c|}
\hline No. & Tahun & Jumlah \\
\hline 1 & 2017 & 4 Kasus \\
\hline 2 & 2018 & 12 Kasus \\
\hline 3 & 2019 & 5 Kasus \\
\hline \multicolumn{2}{|c|}{ Total } & 21 Kasus \\
\hline
\end{tabular}

Sumber dari : Polres Gorontalo Kota, April 2019

${ }^{32}$ Ibid 
Melihat data yang ada, dari aspek litigasi tentunya kebijakan yang dapat diambil oleh penegak hukum dalam hal ini kepolisian terkhusus Polres Gorontalo Kota terkait kasus yang melibatkan anak sebagai pelakunya, menitikberatkan pada kebijakan hukum yang berorientasi pada keadilan restoratif sebagaimana diamanatkan oleh Undang-Undang Nomor 11 Tahun 2012 Tentang Sistem Peradilan Pidana Anak.

Keadilan restoratif sebagaimana tertuang dalam Pasal 1 Angka 6 UndangUndang Nomor 11 Tahun 2012 Tentang Sistem Peradilan Pidana Anak merupakan “penyelesaian perkara tindak pidana dengan melibatkan pelaku, korban, keluarga pelaku/korban, dan pihak lain yang terkait untuk bersama-sama mencari penyelesaian yang adil dengan menekankan pemulihan kembali pada keadaan semula, dan bukan pembalasan.” Guna mewujudkan keadilan restoratif tersebut maka dicetuskanlah diversi yang merupakan pengalihan penyelesaian perkara Anak dari proses peradilan pidana ke proses di luar peradilan pidana, dari litigasi ke non litigasi.

Akan tetapi, dalam prosesnya kebijakan hukum penanggulangan kejahatan yang menitikberatkan pada keadilan restoratif semata tentunya tidak akan berjalan efesien, perlu dukungan dari berbagai aspek guna efektifitas dan efisensi penerapannya, sebab upaya penanggulangan kejahatan tidak hanya berbicara tentang aspek penal tapi juga aspek non penal. Terlebih lagi dalam kasus yang melibatkan anak, penjatuhan hukuman melalui media hukum pidana haruslah memperhitungkan aspek biaya dan hasil (cost and benefit principle), agar terdapat keberimbangan. 
Kebijakan penanggulangan kejahatan atau dapat disebut pula politik kriminal pada dasarnya memiliki tujuan utama untuk melindungi masyarakat guna tercapainya taraf hidup yang lebih baik pada masyarakat. Oleh karenanya dalam kebijakan penanggulangan kejahatan juga memiliki integrasi dengan kebijakan sosial serta merupakan bagian dari kebijakan yang lebih luas. Hal ini ditegaskan oleh G.P. Hoefnagels yang tergambarkan melalui skema berikut $:^{33}$

Skema 1.

\section{Criminal Policy}

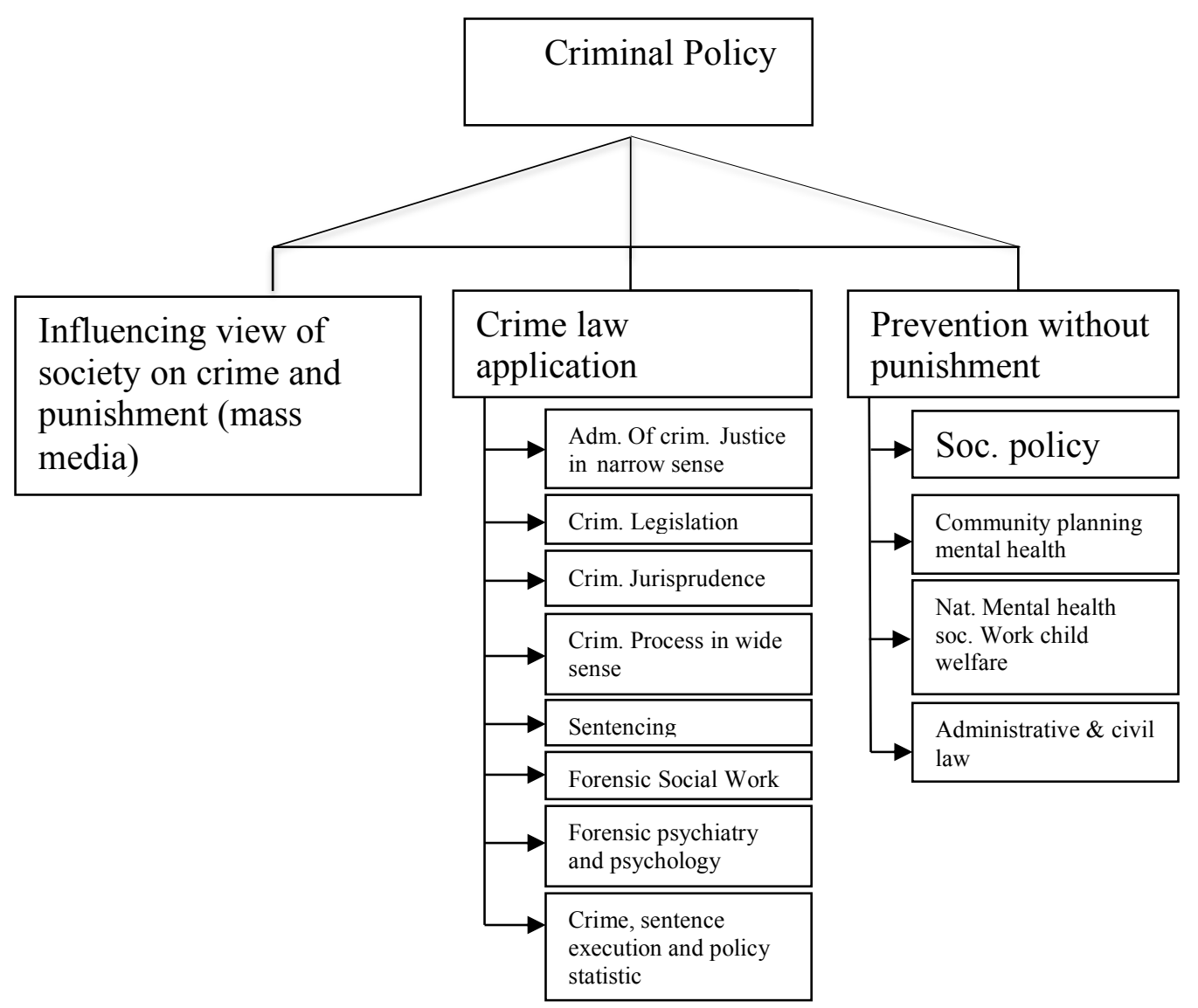

Skema tersebut menggambarkan bahwa kebijakan penanggulangan kejahatan dapat diimplementasikan dengan cara : mempengaruhi pandangan masyarakat

${ }^{33}$ Barda Nawawi Arief. Op.Cit. hlm. 45 
mengenai kejahatan dan pemidanaan melalui media massa (Influencing view of society on crime and punishment / mass media), kemudian penerapan hukum pidana (criminal law application) yang merupakan jalur penal, dan pencegahan tanpa pidana (prevention without punishment). Sehingga jelas bahwasanya dalam upaya penanggulangan kejahatan ada korelasi antara jalur penal dan non penal, sebagaimana tergambarkan dalam skema berikut ini:

Skema 2. Korelasi Penal dan Non Penal

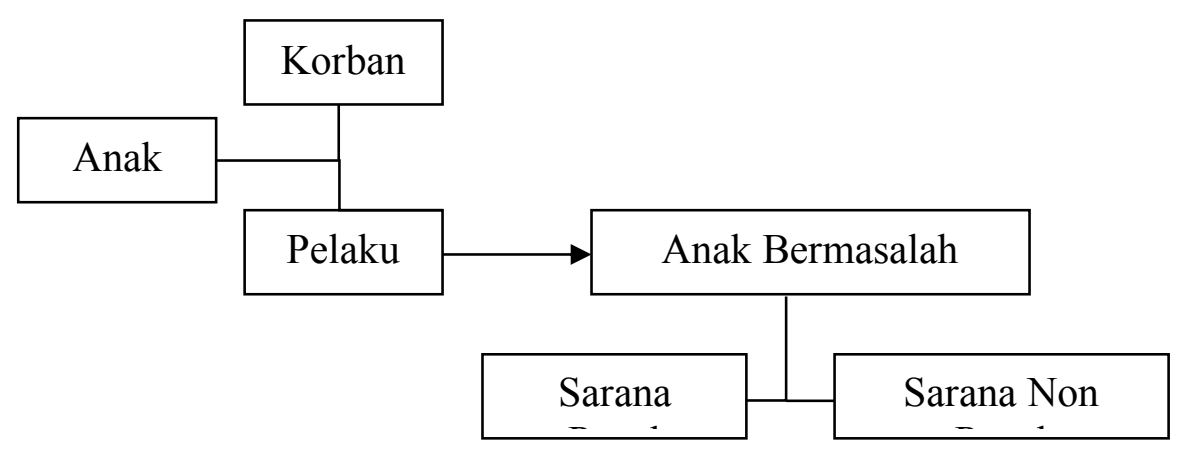

Prof. Sudarto bahkan dalam perspektif yang lebih progresif mengemukakan bahwa “dalam upaya penanggulangan kejahatan yang menempatkan hukum pidana sebagai protagonis dalam penumpasan aspek negatif modernisasi masyarakat maka hendaknya disinergikan dengan kebijakan sosial serta dintegrasikan dengan rencana pembangunan nasional." 34

Kebijakan penanggulangan kejahatan dengan cara mempengaruhi pandangan masyarakat mengenai kejahatan dan pemidanaan melalui media massa (Influencing view of society on crime and punishment / mass media) bertujuan untuk mengkonsepsikan kejahatan dalam hal ini tindak pidana dan pemidanaannya dalam

${ }^{34}$ Sudarto. Hukum dan Hukum Pidana. Alumni. Bandung. 2007. hlm. 38 
hukum positif di Indonesia, serasional mungkin sehingga masyarakat paham akan konsekuensi dari tindakan-tindakan yang dilakukannya, dengan begitu maka akan menciptakan masyarakat sadar hukum yang berimplikasi pada optimalnya sinergitas hukum positif dan penegakan hukumnya dalam menekan angka kriminalitas, terkhusus kriminalitas yang dilakukan oleh anak.

Media massa juga berperan dalam membangkitkan kembali sisi kemanusiaan masyarakat sekaligus menguatkan keteguhan akan kapasitasnya untuk melakukan hal baik, melalui pemberitaan yang positif karena dalam pengamatan penulis, media massa saat ini lebih banyak menampilkan adegan kekerasan, program siaran untuk orang dewasa serta berita tentang kejahatan secara vulgar sehingga disadari atau tidak telah menciptakan teror psikis tersendiri dalam diri masyarakat.

Dari pespektif litigasi / penal, penerapan hukum pidana (criminal law application) merupakan kebijakan terpopuler saat ini. Undang-Undang Nomor 3 Tahun 1997 Tentang Pengadilan Anak jo Undang-Undang No. 11 Tahun 2012 Tentang Sistem Peradilan Anak, merupakan pedoman utama dalam proses pemidanaan anak yang mengutamakan keadilan restoratif melalui jalur diversi, disamping tentunya ada Kitab Undang-Undang Hukum Pidana dan Kitab UndangUndang Hukum Acara Pidana sebagai acuan lainnya.

Soedjono Dirdjosisworo dalam perspektifnya juga mengemukakan penanggulangan kejahatan via jalur penerapan hukum pidana perlu kiranya untuk:

1. membina dan membenahi aparatur penegak hukum yang meliputi struktur organisasi, personalia dan perlengkapan yang diselaraskan dengan perkembangan pola kriminalitas yang dipengaruhi oleh perkembangan masyarakat dan teknologi;

2. untuk mendayagunakan prosedur dan mekanisme peradilan pidana yang diselaraskan dengan citra penanggulangan kriminalitas seperti peradilan yang cepat, murah tepat dan tidak pandang bulu, pembaharuan perundang- 
undangan yang diselaraskan dengan tuntutan perkembangan sosial dan teknologi,

3. koordinasi terpadu antar penegak hukum dan antar aparatur pemerintahan terkait $^{35}$

Kebijakan penanggulangan kejahatan yang terakhir yakni pencegahan tanpa pidana (prevention without punishment) tentunya menjadi kebijakan yang menarik, terlebih kaitannya dengan anak yang berhadapan dengan hukum. Barda Nawawi Arief mengemukakan

“pencegahan tanpa pidana sebagai bentuk kebijakan sosial diarahkan pada penggarapan masalah kesehatan jiwa masyarakat (social hygiene) baik secara individual sebagai anggota masyarakat maupun ksehatan/kesejahteraan keluarga termasuk didalamnya masalah kesejahteraan anak/remaja, serta masyarakat luas pada umumnya."

Hal ini tentunya sesuai dengan pendapat yang dikemukakan oleh G.F. Hoefnagels yang tergambarkan dalam skema 1. Criminal policy yang menekankan pada perbaikan mental health, national mental health social work dan child welfare .

Sudarto juga menyatakan bahwa "kegiatan seperti karang taruna, pramuka, palang marah remaja dan penggarapan kesehatan jiwa masyarakat melalui pendidikan agama maupun kegiatan kerohanian juga termasuk dalam upaya pencegahan dan penanggulangan kejahatan." ${ }^{36}$ Kegiatan terarah seperti ini tentunya akan membentuk pribadi masyarakat yang berjiwa sehat dengan mentalitas yang baik sehingga dapat sejalan dengan cita-cita bangsa. Sebab, lingkungan dan pergaulan yang baik akan membentuk karakter yang baik dan humanis serta produktif.

35 Soedjono Dirdjosisworo. Pemeriksaan Pendahuluan Menurut KUHAP. Alumni, Bandung. 1982. Hlm. 29-30. Dalam Maidin Gultom. Op.Cit. Hlm. 60-61

${ }^{36}$ Sudarto. Kapita Selekta Hukum Pidana. Alumni. Bandung. 2006. hlm. 144 


\section{SIMPULAN}

1. Faktor yang menyebabkan terjadinya tindak pidana penganiayaan menggunakan panah wayer oleh anak di Kota Gorontalo adalah faktor lingkungan pergaulan yang erat kaitannya dengan mengendurnya ikatan sosial dan keluarga, penyalahgunaan alkohol, obat-obat terlarang dan zat adiktif, serta adanya dorongan-dorangan ide dan sikap yang dibentuk oleh media massa. Persoalan disorganisasi keluarga ini tidak dapat dipungkiri berdampak pada pembentukan intelektual dan mental anak yang mengakibatkan terjadinya penyimpangan perilaku sosial anak ketika memasuki masa remaja. Sehingga diperlukan harmonisasi dalam keluarga, pemutusan mata rantai narkotika serta penghilangan akses minuman beralkohol oleh anak serta memainkan peran media massa. Media massa yang sehat tentunya akan berpengaruh terhadap efektifnya penanggulangan kejahatan.

2. Kebijakan penanggulangan kejahatan dengan cara mempengaruhi pandangan masyarakat mengenai kejahatan dan pemidanaan melalui media massa (Influencing view of society on crime and punishment / mass media) bertujuan untuk mengkonsepsikan kejahatan dalam hukum positif di Indonesia, serasional mungkin sehingga masyarakat paham akan konsekuensi dari tindakan yang dilakukannya. Dari pespektif litigasi / penal, kebijakan penanggulangan kejahatan via jalur penerapan hukum pidana (criminal law application) merupakan pilihan terpopuler saat ini. Undang-Undang Sistem Peradilan Anak, merupakan pedoman utama dalam proses pemidanaan anak yang mengutamakan keadilan restoratif melalui jalur diversi. Kebijakan pencegahan tanpa pidana (prevention without punishment) melalui kegiatan 
terarah tentunya akan membentuk pribadi masyarakat yang berjiwa sehat dengan mentalitas yang baik.

\section{DAFTAR PUSTAKA}

\section{Buku:}

Anwar, Yesmil dan Adang. 2008. Pembaharuan Hukum Pidana ; Reformasi Hukum Pidana, Jakarta : Grasindo.

Arief, Barda Nawawi. 2011. Bunga Rampai Kebijakan Hukum Pidana, Semarang : Fajar Interpratama.

Effendy, Marwan. 2014. Teori Hukum Dari Perspektif Kebijakan, Perbandingan dan Harmonisasi Hukum Pidana, Ciputat: Referensi.

Goode, William J. 1991. Sosiologi Keluarga, Jakarta : Bumi Aksara.

Gultom, Maidin. 2008. Perlindungan hukum terhadap anak dalam Sistem Peradilan Pidana anak di Indonesia, Bandung; PT. Rafika Aditama.

Koentjoro, Diana Halim. 2004. Hukum Administrasi Negara, Bogor : Ghalia Indonesia.

Marzuki, Peter Mahmud. 2010. Penelitian Hukum. Jakarta : Kencana Prenada Media Group.

McQuail, Denis. 2000. Mass Communication Theories, Fourth edition, London : Sage Publication.

Mulyadi, Lilik. 2009. Kajian Kritis dan Analitis Terhadap Dimensi Teori-Teori Kriminologi Dalam Perspektif Ilmu Pengetahuan Hukum Pidana Modern, Malang : Pengadilan Negeri Kepanjen.

Mulyadi, Mahmud. Surbakti, Feri Antoni. 2010. Politik Hukum Pidana Terhadap kejahatan Korporasi, Medan : PT Softmedia.

Soerjono Soekanto. 1994. Sosiologi Suatu Pengantar, Jakarta : Raja Grafindo Persada.

Sudarto. 2006. Kapita Selekta Hukum Pidana, Bandung : Alumni. . 2007. Hukum dan Hukum Pidana, Bandung : Alumni.

\section{Artikel dalam Jurnal}

Setiawan, Aria Aditya, "Peran Media Massa Dalam Meningkatkan Kualitas Kepemerintahan Lokal Berbasis Human Security di Kota Jayapura", Politika Jurnal Ilmu Politik. Vol. 2. No. 2. 2013, Semarang : Universitas Diponegoro

Hapsari, Indira. Soponyono, Eko. R.B. Sularto. "Kebijakan Hukum Pidana Dalam Upaya Penanggulangan Tindak Pidana Narkotika Pelaku Anak". Diponegoro Law Journal. Vol. 5. No. 3. 2016. Semarang : Universitas Diponegoro. 
Wilodati. "Pengoptimalisasian Kembali Fungsi Keluarga Sebagai Peletak Dasar Kepribadian Anak". Jurnal Keluarga. Bandung : Universitas Pendidikan Indonesia

\section{Artikel dalam Internet}

Badan Narkotika Nasional Provinsi Gorontalo. Banyak Remaja Miras \& Ngelem, Ini Pesan Kabid P2M BNNP Gorontalo. https:/gorontalo.bnn.go.id/beritakegiatan/banyak-remaja-miras-ngelem-inipesan-kabid-p2m-gorontalo/. Diakses 20-08-2019

Badan Narkotika Nasional Republik Indonesia dan LIPI. Executive Summary Survey Penyalahgunaan dan Peredaran Gelap Narkoba 2018. Hlm. 19. https://ppid.bnn.go.id/wpcontent/uploads/sites/2/2019/02/hasil_lit_bnn_2018.pdf. Diakses 20-08-2019

Badan Narkotika Nasional Republik Indonesia. Daftar Kawasan Rawan Narkoba Di Indonesia Tahun 2019. Hlm. 19. https://ppid.bnn.go.id/wpcontent/uploads/sites/2/2019/07/Kawasan-Rawan-Narkoba.pdf . Diakses 20-082019

Badan Pengembangan dan Pembinaan Bahasa Kementerian Pendidikan dan Kebudayaan Republik Indonesia. Kamus Besar Bahasa Indonesia Versi Daring: 1.4.9.220190308150813. https://kbbi.kemdikbud.go.id/entri/penganiayaan Diakses 1803-2019

Dengo, Franco. Teror Panah Wayer Di Gorontalo Belum Berhenti. Beritatagar.id 1 Maret 2019. https://beritagar.id/artikel/berita/teror-panah-wayer-di-gorontalo-belumberhenti. Diakses 20 Maret 2019

, Teror Panah Wayer Menghantui Kota Gorontalo. Beritatagar.id. 14 Feberuari 2019. https://beritagar.id/artikel/berita/teror-panah-wayer-menghantui-kotagorontalo . Diakses 20 Maret 2019

Fajriansyach. Tiga Pelaku Panah Wayer Dibekuk, Ini Orangnya. http://hargo.co.id/berita/tiga-pelaku-panah-wayer-dibekuk-ini-orangnya.html . 13 Februari 2019. Diakses 21-08-2019

Hukum Online. Pedang Bermata Dua. Hukumonline.com ; 4 September 2014. https://www.hukumonline.com/berita/baca/lt540835393d0aa/pedang-bermatadua/. Diakses 10 -8-2019.

Tawaulu, Anshar. Peranan Media Sosial dalam Membentuk Karakter Generasi Muda.https://www.kompasiana.com/pojokjalan/59b81bc6830de00acf4b98f2/per anan-media-sosial-dalam-membentuk-karakter-generasi-muda. 13 September 2017. Diakses Tanggal 21-08-2019

Wumu, Arimin J. Polsek Dungingi Kota Gorontalo Amankan Dua Pelaku Penembakan Panah Wayer Yang Meresahkan Warga. http://antpnews110.com/polsekdungingi-kota-gorontalo-amankan-dua-pelaku-penembakan-panah-wayer-yangmeresahkan-warga/ . 7 April 2019. Diakses 21-08-2019. 